\title{
Factors impacting survival of mature honey bee drones kept in small laboratory cages
}

\author{
Hossam F. Abou-Shaara*, Mona I. Elbanoby \\ Department of Plant Protection, Faculty of Agriculture, Damanhour University, Damanhour, 22516, Egypt \\ ${ }^{\star}$ Corresponding author, E-mail: hossam.farag@agr.dmu.edu.eg
}

\begin{abstract}
Maintaining honey bee drones in the laboratory is very important for some purposes, such as instrumental insemination of bee queens and studying effects of pesticides on drones. Few studies have been performed on the survival of mature bee drones in the laboratory. In this study, factors impacting the survival of mature bee drones were investigated. Small cages were used to facilitate observation of drones. The study showed that some factors can impact the survival of drones passively. These factors were sugar candy as feeding, collecting drones from colonies with egg laying workers, and caging drones without attendant bees. Outcome was improved when the attendant workers were nursing bees either from the same colony from which the drones were collected (preferable) or from another colony. Placing caged drones in complete darkness was better than under light. Avoiding these factors can help increasing the survival of caged drones under laboratory conditions. Likely this is the first study to examine factors that could impact the survival of bee drones in the laboratory.
\end{abstract}

Key words: Apis mellifera, cages, candy, drone, mortality, workers.

Abbreviations: ESM, estimated survival means.

\section{Introduction}

Honey bee drones have a main role in the mating of virgin bee queens. They do not participate in foraging or other activities within colonies, except thermoregulation (Harrison 1987). Therefore, drones do not exist in the colonies during all months. The colonies tend to rear drones only during active seasons but not during winter (Boes 2010). The number of drones inside the colonies is not higher than workers and as low as a few hundred. Unfertilized eggs, either from queens or laying workers, give drones (Ratnieks, Keller 1998; Gençer, Firatli 2005). Regulating the production of the unfertilized queen eggs can help controlling the drone population in the colonies (Wharton et al. 2007). Sometimes, diploid eggs can give drones (Woyke 1964). These diploid drones do not survive inside the colonies because workers eat the larvae before completing their development (Woyke 1963). Drones reach maturity after 8 to 14 days from emergence (Jaycox 1961; Cobey et al. 2013). The mature drones fligh outside the colonies to search for virgin queens for mating. The mating of queens occurs in the air (Gary 1963) at specific areas known as drone congregation areas. These areas can be detected using a portable radar unit (Loper et al. 1987). The virgin queens mate with large number of drones, from 7 to 45 (Taber, Wendel 1985; Moritz et al. 1996; Neumann, Moritz 2000; Cobey 2007). Such a high number of mates is good for colony performance (Delaplane et al. 2015).
The natural mating of honey bee queens is not always safe because it depends on the climatic conditions and absence of bee predators. Unsuitable environmental conditions (Lensky, Demter 1985; El-Niweiri, Moritz 2011), and the presence of bee diseases and pests (Cobey 2007) can greatly hinder mating and may cause loss of the queen. Moreover, flight activity of bee drones can be impacted by some factors including temperature and light conditions (Neves et al. 2011). Also, infected drones can transmit diseases (e.g. deformed wing virus) to queens (Amiri et al. 2016). Hence, instrumental insemination is a suitable alternative to the natural mating. Although naturally mated queens perform better than those instrumentally inseminated ones (Kaftanoglu, Peng 1982), still this way of mating is a good option to overcome obstacles of natural mating. Also, instrumental insemination allows to control the genetic source of drones and queens (Cobey et al. 2013). Drones from queen eggs and from worker eggs (i.e. egg laying workers) can be used to collect semen from them for instrumental insemination. Sperm viability and sperm length do not differ significantly between the two types of drones (Gençer, Kahya 2011). Keeping drones in the laboratory is important for instrumental insemination. In this regard, it is especially important that maintaining bee drones under laboratory conditions does not affect semen quality (Ben Abdelkader et al. 2014).

Moreover, keeping drones in cages is required for some laboratory investigations, such as studying the effects of 
pesticides (Abou-Shaara et al. 2017a; Kairo et al. 2017) or Varroa control materials on drones (Abou-Shaara et al. 2017b), and to investigate effects of diseases on drones (Huang et al. 2012). Drones are highly sensitive to laboratory conditions and infection with diseases (Tanner et al.2012). Few studies have been done on factors affecting survival of drones in the laboratory. In this study, major factors that could impact the survival of bee drones were identified. Specific recommendations were presented for maintaining bee drones in the laboratory.

\section{Materials and methods}

\section{Honey bees}

Honey bee drones and workers from Egyptian Carniolan bee colonies were collected in specific cages during August 2017. The drones were collected from the lateral combs (i.e. mature drones). The abdomens of some random drones were pressed for observation of semen to ensure that drones were mature before the collection of samples. Small cages with a small number of drones were used in this study to study the impacts of the investigated factors on drones. The cages used in this study were Petri dishes modified to be suitable for holding bees, as described by Abou-Shaara and Elbanoby (2017). The cage shape and dimensions are shown in Fig. 1.

All of the following experiments were run at the same time to determine factors affecting survival of bee drones. The cages were exposed to $12 \mathrm{~h}$ light and $12 \mathrm{~h}$ dark, except when mentioned, and temperature around $31^{\circ} \mathrm{C}$, close to the recommended temperatures between 31 and $34{ }^{\circ} \mathrm{C}$ (Jaycox 1961). The survival of bee drones was recorded every $12 \mathrm{~h}$. All cages were supplied with honey candy (honey saturated with powdered sugar) except when sugar candy was used. Each group was represented by six cages, each with four drones, with a total of 24 drones per group. Two attendant workers from brood combs were placed in all cages, except when mentioned. The total number of drones used in all the experiments was 168 .

\section{Feeding type}

Two feeding types were compared: (i) honey candy (honey saturated with powdered sugar) and (ii) sugar candy (water saturated with powdered sugar). Solid feeding was tested because it is easy to transport the cages with solid rather than liquid feed (i.e. syrup).

\section{Workers presence}

Honey bee drones need workers to feed them. The suitable number of workers is one worker per two drones (Jaycox 1961). To test whether drones can survive without workers, two groups were compared: one group with six cages, each with four drones and two workers, and the second group with six cages, each with four drones without workers.

\section{Workers source}

Two groups were compared to test whether attendant workers should be from the same colony from which drones were collected or from any colony. The first group contained six cages, each with four drones with two attendant workers from the same colony, while in the second group the attendant workers were from another colony.

\section{Drones from egg laying workers}

Survival was compaerd in six cages, each with four drones and two workers from colonies with queens (group I), and six cages, each with four drones and two workers from colonies without queens and with egg laying workers (group II).

\section{Age of attendant workers}

Two groups were compared: the first group contained bee workers from brood combs (nurse bees) while the second group contained bee workers from the lateral combs (forager bees) with caged drones (two workers and four drones per cage, and six cages per group).

\section{Impact of light}

Two groups were compared. Six cages of the first group were exposed to $12 \mathrm{~h}$ light and $12 \mathrm{~h}$ dark while those of
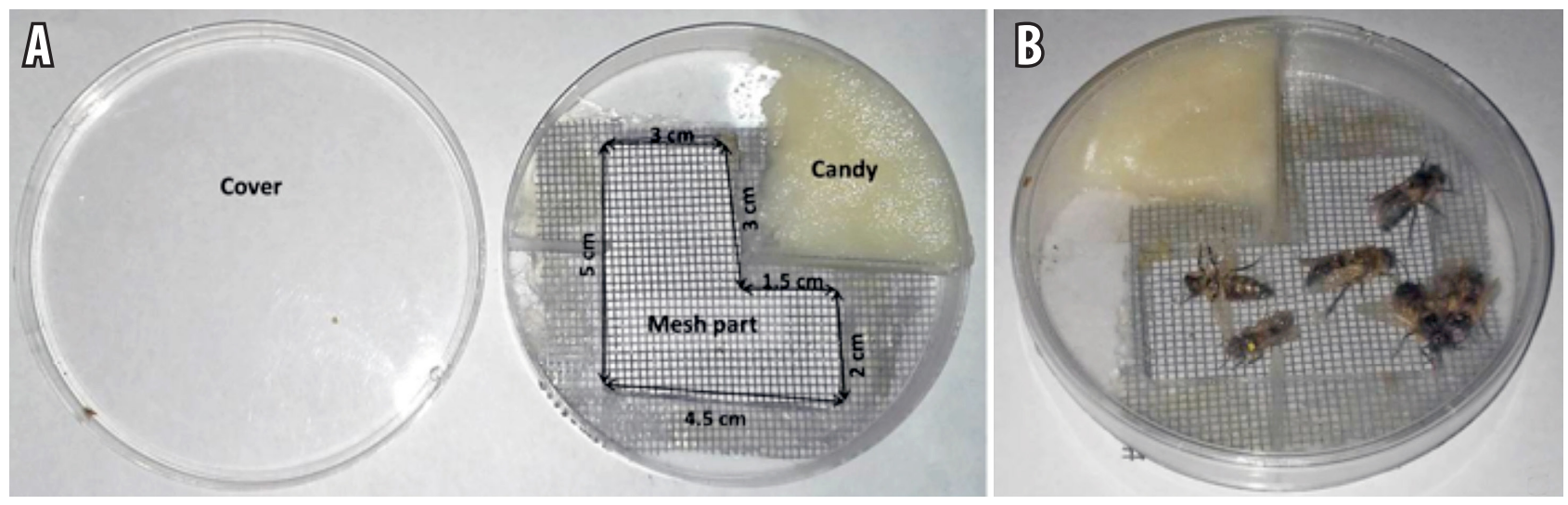

Fig. 1. Cages used in the experiments. A, dimensions of the cage; B, candy, four drones and two workers inside the cage. 
the second group were placed in a wooden box to ensure complete darkness. The wooden box was slightly opened to allow the respiration of the caged bees. Four drones and two attendant workers were placed in each cage.

\section{Statistical analysis}

The survival curves were compared using the KaplanMeier test. Also, the estimated survival means (ESM) of the test groups were calculated. The Log Rank (MantelCox test) was used to detect the significant differences $(P$ $\leq 0.05$ ) between the groups. The analysis was performed using SPSS v. 16.

\section{Results}

During the experiments the drones were able to survive for different periods according to treatment group. There were no any observable problems in regard to movement or feeding of drones inside the cages. Trophallaxis, food exchange, was observed between drones and workers and sometimes between drones only. Moreover, drones were able to feed themselves on the candy. Drones did not defecate more inside the cages.

Drones fed on honey candy were able to survive significantly longer (Fig. 2) than those fed on sugar candy (Mantel-Cox test $=19.087, P=0.000,<0.05)$. The ESM was $86.50 \pm 8.04 \mathrm{~h}$ ( 3.60 days $)$ and $53.50 \pm 2.79 \mathrm{~h}$ ( 2.23 days $)$ for honey candy and sugar candy group, respectively.

Drones with attendant workers ( 1 worker and 2 drones) survived significantly longer (Fig. 3) than those without attendant workers under the same conditions and feeding type (honey candy) (Mantel-Cox test $=15.571, P=0.000$, $<0.05)$. The ESM was $86.50 \pm 8.04 \mathrm{~h}$ (3.60 days) and 52.00 $\pm 3.73 \mathrm{~h}$ ( 2.17 days) for drones with and without attendant

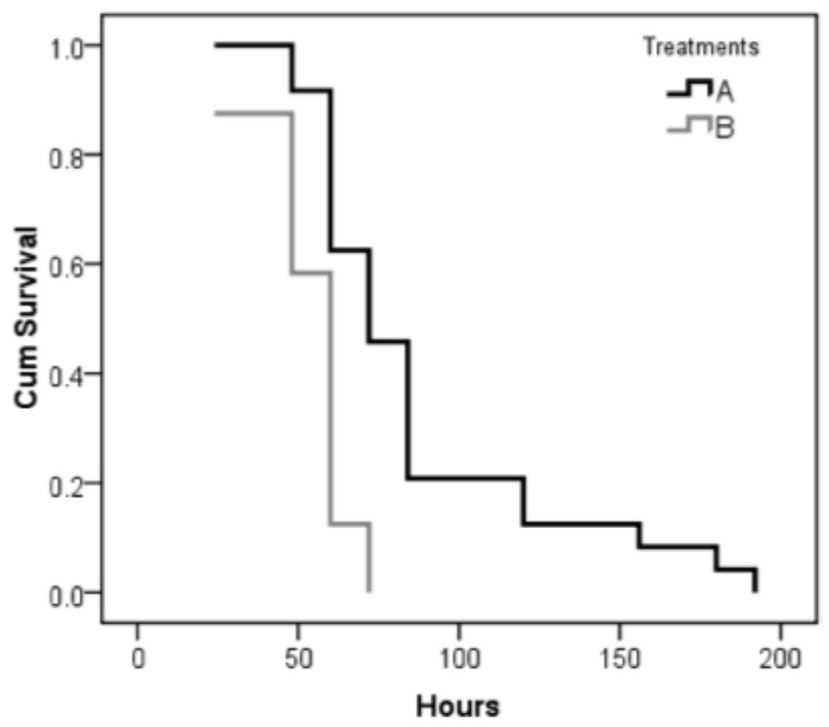

Fig. 2. Cumulative survival of drones from the honey candy group (A) and sugar candy group (B). Six cages and 24 drones per group were used. workers, respectively.

Under the same conditions, drones with attendant workers from the same colonies from which drones were collected survived insignificantly longer (Fig. 4) than drones from colonies with attendant workers from other colonies (Mantel-Cox test $=0.930, P=0.335,0.05$ ). The ESM was $86.50 \pm 8.04 \mathrm{~h}$ (3.60 days) and $74.00 \pm 5.29 \mathrm{~h}(3.08$ days) for drones with attendant workers from the same and different colonies, respectively.

The survival of drones from colonies with queens was significantly higher (Fig. 5) than those from colonies with egg laying workers (Mantel-Cox test $=8.449, P=0.004$, < 0.05 ). The ESM was $86.50 \pm 8.04 \mathrm{~h}$ (3.60 days) and $58.00 \pm$ $4.43 \mathrm{~h}$ ( 2.41 days) for drones from colonies with queens and from colonies with egg laying workers, respectively.

The survival of drones accompanied by nurse workers collected from brood combs was not significantly higher (Fig. 6) than those accompanied by forager workers collected from lateral combs (Mantel-Cox test $=2.800, P=$ $0.094,>0.05)$. The ESM was $86.50 \pm 8.04 \mathrm{~h}$ (3.60 days) for drones accompanied by nurse bees and $68.50 \pm 5.28 \mathrm{~h}(2.85$ days) for drones accompanied by forager bees.

Drones exposed to $0 \mathrm{~h}$ light $(24 \mathrm{~h}$ dark) survived insignificantly longer (Fig. 7) than drones exposed to 12 h light (Mantel-Cox test $=0.314, P=0.576,>0.05$ ). The ESM was $92.50 \pm 4.70 \mathrm{~h}$ (3.85 days) and $86.50 \pm 8.04 \mathrm{~h}$ (3.60 days) for drones exposed to $0 \mathrm{~h}$ light and to $12 \mathrm{~h}$ light, respectively.

\section{Discussion}

The main source of energy for bees is feeding. Honey candy was better than sugar candy for survival of bee drones. Drones were able to survive up to $192 \mathrm{~h}$ (8 days) in case

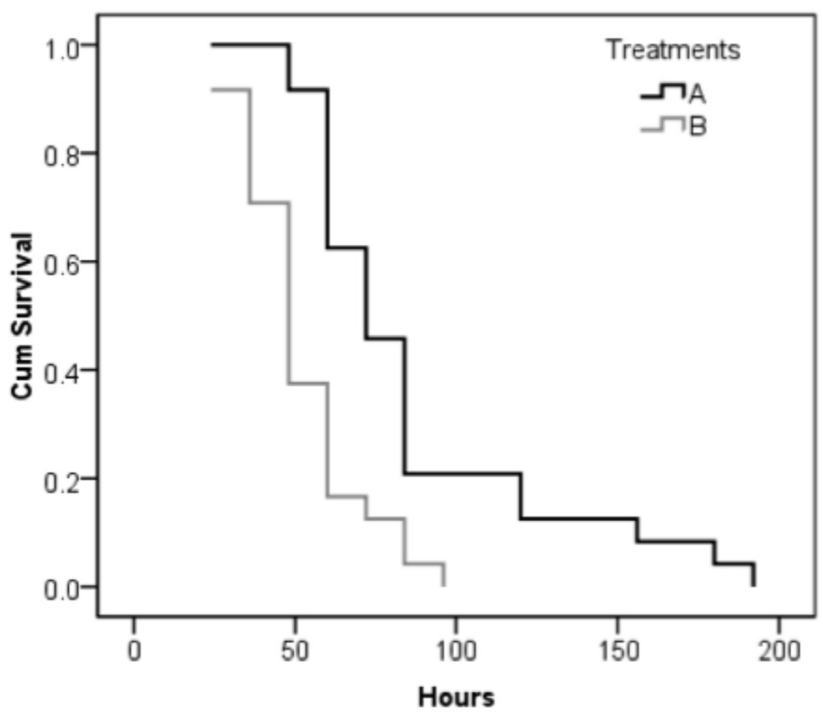

Fig. 3. Cumulative survival of drones with attendant workers (A) and without attendant workers (B). Six cages and 24 drones per group were used. 


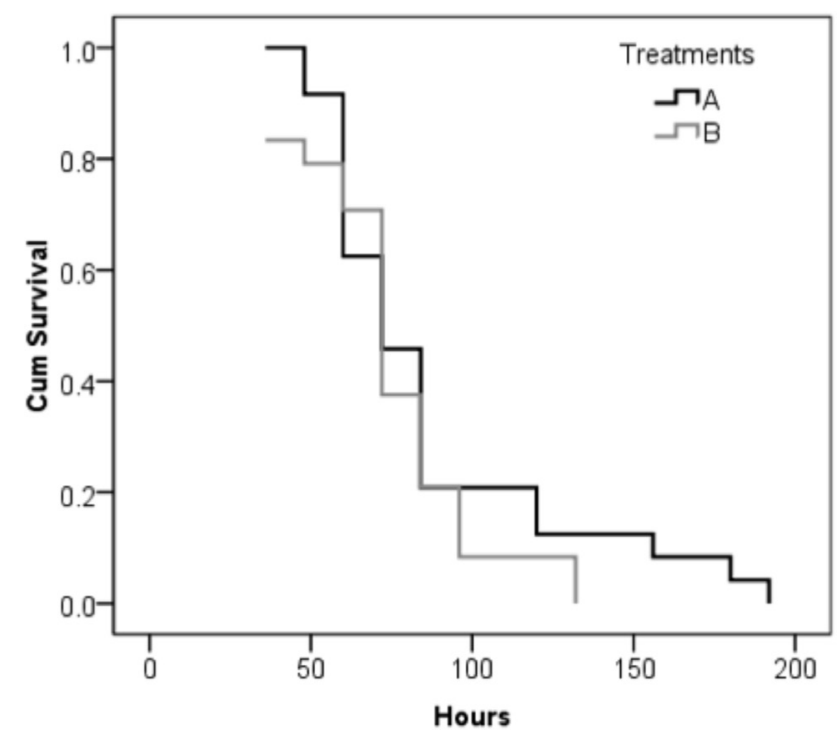

Fig. 4. Cumulative survival of drones with attendant workers from the same colonies (A) and with attendant workers from other colonies (B). Six cages and 24 drones per group were used.

of honey candy and only up to $72 \mathrm{~h}$ ( 3 days) for sugar candy group. Drones were possibly able to better utilize honey candy as source of energy more than sugar candy. The presence of honey beside powdered sugar perhaps provided caged drones with more nutrients than sugar candy. Accordingly, the survival of caged bee queens was promoted when honey candy was used for feeding (AbouShaara, Elbanoby 2017). In contrast, honey only was better than sugar candy alone or mixed with honey in promoting survival of caged queens (Bigio et al. 2012), perhaps since the liquid feeding was more easily utilized by caged bees.

Drones without attendant workers were able to survive

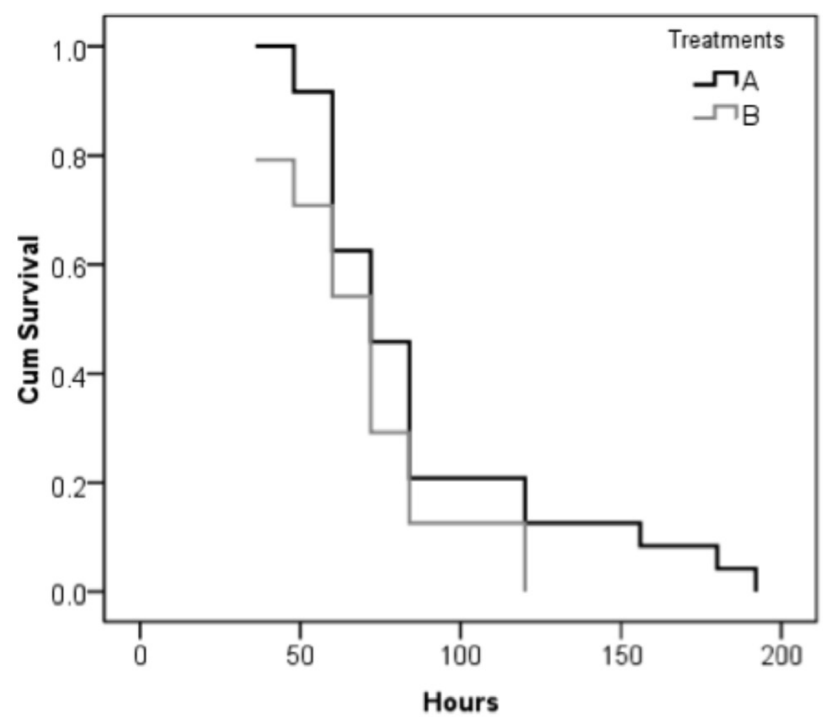

Fig. 6. Cumulative survival of drones accompanied by nurse bees (A) and drones accompanied by forager bees (B). Six cages and 24 drones per group were used.

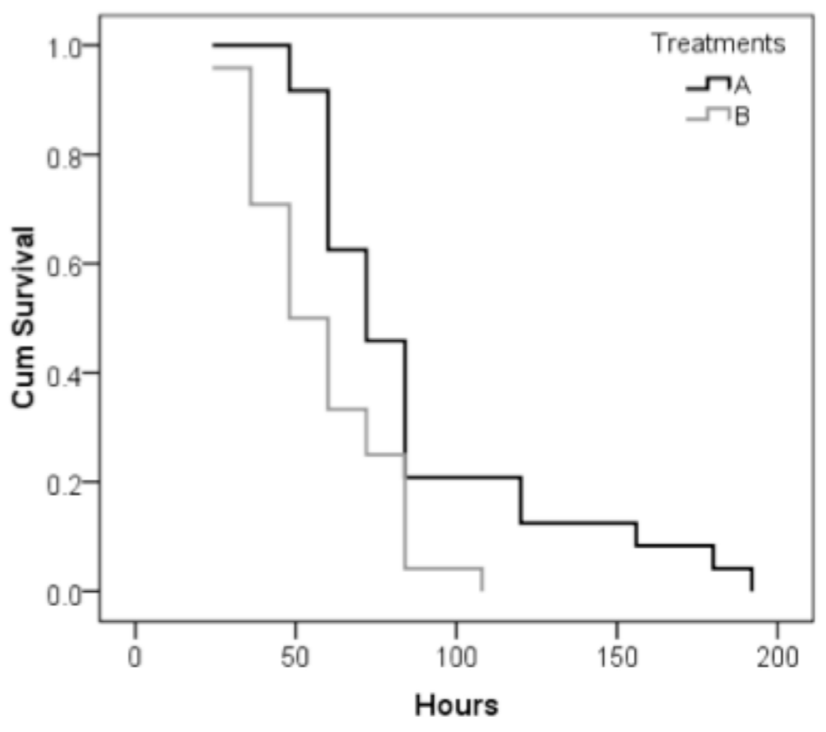

Fig. 5. Cumulative survival of drones from colonies with queens (A) and from colonies without queens and with egg laying workers (B). Six cages and 24 drones per group were used.

only up to $96 \mathrm{~h}$ (4 days) while with attendant workers up to $192 \mathrm{~h}$ (8 days). This reflects the important role of workers in feeding the caged drones. In contrast, caged drones can attain maturity without attendant workers (Jaycox 1961). This can be explained by the ability of bee drones to feed themselves or by trophallaxis as observed during the study.

Drones caged with workers from the same colony of drones or from a different colony showed no significant effect on survival. Survival reached up to $132 \mathrm{~h}$ (5.5 days) and $192 \mathrm{~h}$ (8 days) for workers from different colonies and the same colony, respectively. Thus, it is preferable to collect drones and attendant workers from the same colonies.

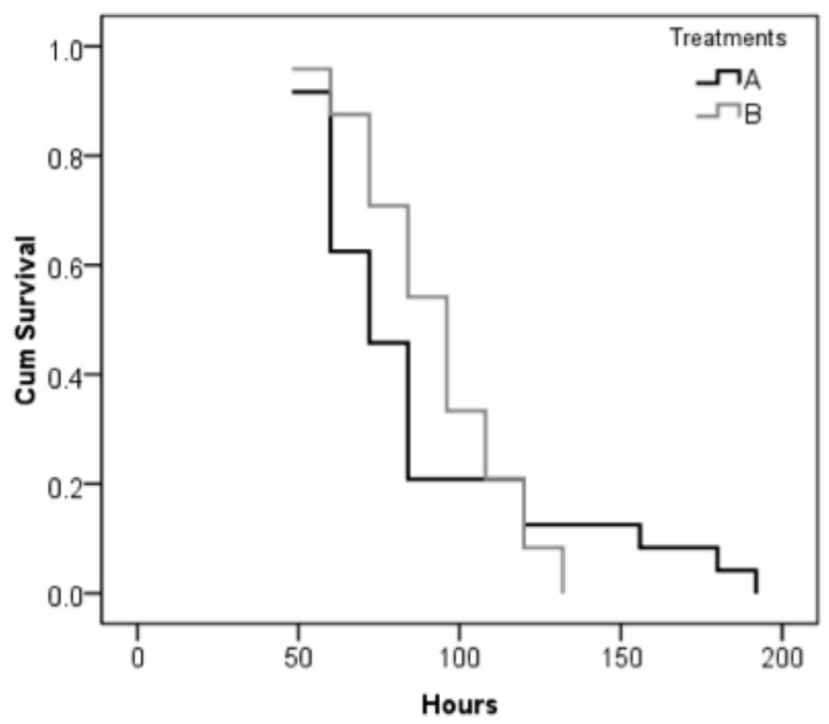

Fig. 7. Cumulative survival of drones exposed to $12 \mathrm{~h}$ light (A) and drones exposed to $0 \mathrm{~h}$ light (B). Six cages and 24 drones per group were used. 
However, it is anticipated that workers from different colonies than drone colonies can feed caged drones without any problems.

Drones from egg laying workers survived to $108 \mathrm{~h}$ (4.5 days) while drones from queen eggs survived up to $192 \mathrm{~h}$ (8 days). The low survival of drones from egg laying workers may be due to the low quality of drones. The eggs are more sensitive to desiccation with slow development in case of laying workers (Wegener et al. 2010). Drones from queen eggs are larger, heavier and with greater number of spermatozoa than those from worker eggs (i.e. egg laying workers) (Gençer, Firatli 2005). Also, sperm concentration is higher and sperm cells are more numerous in drones from colonies with queens than laying worker colonies (Gençer, Kahya 2011). These studies reflect the low quality of drones from colonies with laying workers.

Presence of attendant workers from brood combs (nurse bees) or from lateral combs (forager bees) did not significantly affect survival of drones. This can be explained by the ability of caged drones to obtain food without help from the workers. It was found that forager bees produce a substance, ethyl oleate, and transport it to younger bees via trophallaxis to delay age at beginning of foraging (Leoncini et al.2004). Trophallaxis of forager workers with other bees can occur. The maximum survival of drones reached $192 \mathrm{~h}$ (8 days) and $120 \mathrm{~h}$ (5 days) when attendant workers were from brood combs and lateral combs, respectively. Thus, it is preferable to collected attendant workers from brood combs.

Complete darkness or exposure to $12 \mathrm{~h}$ light did not impact the survival of drones significantly. The maximum survival was $192 \mathrm{~h}$ (8 days) and 132h (5.5 days) for $12 \mathrm{~h}$ light and $0 \mathrm{~h}$ light, respectively. However, most drones were able to survive better in complete darkness than in $12 \mathrm{~h}$ light. Exposure to light may be make drones more active (more movements with trails to flight) which requires more energy than in darkness. The flight activity of honey bees depends on light and can be developed in response to the cycles of dark and light (Kefuss, Nye 1970). However, bees can do difficult tasks like comb construction in the dark but not in the light (Morse 1965). Also, bees are able to perform trophallaxis and other activities in the dark.

\section{Conclusions}

The study investigated effects of some factors on the survival of bee drones in the laboratory. Survival of bee drones was significantly affected by feeding type, presence of attendant workers, drone type, worker source, age of attendant workers and light. Survival of mature drones under laboratory conditions can be promoted by use of honey candy as a food source, use of nurse workers from the same colonies of drones as attendant bees, collection of drones from colonies headed by queens, and placing drones in complete darkness. There is a need for development of an optimal feeding type to promote survival of bee drones in the laboratory.

\section{References}

Abou-Shaara H.F., Elbanoby M.I. 2017. Using new cage type for keeping virgin honey bee queens with investigating impacts of feeding type and number of attendant workers. Egypt. Acad. J. Biol. Sci. 10: 81-87.

Abou-Shaara H.F., Staron M., Cermáková T. 2017a. Impacts of sub-lethal doses of amitraz and tau-fluvalinate on some parameters of honey bee workers and drones. Munis Entomol. Zool. 12: 516-523.

Abou-Shaara H.F., Staron M., Cermáková T. 2017b. Impacts of oxalic acid, thymol, and potassium citrate as Varroa control materials on some parameters of honey bees. Turk. J. Vet. Anim. Sci. 41: 238-247.

Amiri E., Meixner M.D., Kryger P. 2016. Deformed wing virus can be transmitted during natural mating in honey bees and infect the queens. Sci. Rep. 6: 33065.

Ben Abdelkader F., Kairo G., Tchamitchian S., Cousin M., Senechal J., Crauser D., Vermandere J.P., Alaux C., Le Conte Y., Belzunces L.P., Barbouche N., Brunet J.-L. 2014. Semen quality of honey bee drones maintained from emergence to sexual maturity under laboratory, semi-field and field conditions. Apidologie 45: 215-223.

Bigio G., Gruter C., Ratnieks F.L.W. 2012. Comparing alternative methods for holding virgin honey bee queens for one week in mailing cages before mating. PLoS One 7: e50150.

Boes K.E. 2010. Honeybee colony drone production and maintenance in accordance with environmental factors: an interplay of queen and worker decisions. Insect. Soci. 57: 1-9.

Cobey S.W. 2007. Comparison studies of instrumentally inseminated and naturally mated honey bee queens and factors affecting their performance. Apidologie 38: 390-410.

Cobey S.W., Tarpy D.R., Woyke J. 2013. Standard methods for instrumental insemination of Apis mellifera queens. J. Apic. Res. 52: 1-18.

Delaplane K.S., Pietravalle S., Brown M.A., Budge G.E. 2015. Honey bee colonies headed by hyperpolyandrous queens have improved brood rearing efficiency and lower infestation rates of parasitic Varroa mites. PLoS One 10: e0142985.

El-Niweiri M.A.A., Moritz R.F.A. 2011. Mating in the rain? Climatic variance for polyandry in the honeybee (Apis mellifera jemenitica). Popul. Ecol. 53: 421-427.

Gary N.E. 1963. Observations of mating behaviour in the honeybee. J. Apic. Res. 2: 3-13.

Gençer H.V., Firatli Ç. 2005. Reproductive and morphological comparisons of drones reared in queenright and laying worker colonies. J. Apic. Res. 44: 163-167.

Gençer H.V., Kahya Y. 2011. Are sperm traits of drones (Apis mellifera L.) from laying worker colonies noteworthy?. J. Apic. Res. 50: 130-137.

Harrison J.M. 1987. Roles of individual honeybee workers and drones in colonial thermogenesis. J. Exp. Biol. 129: 53-61.

Huang Q., Kryger P., Le Conte Y., Moritz R.F.A. 2012. Survival and immune response of drones of a nosemosis tolerant honey bee strain towards N. ceranae infections. J. Invert. Pathol. 109: 297-302.

Jaycox E.R. 1961. The effects of various foods and temperatures on sexual maturity of the drone honey bee (Apis mellifera). Ann. 
Entomol. Soc. Amer. 54: 519-523.

Kaftanoglu O., Peng Y.-S. 1982. Effects of insemination on the initiation of oviposition in the queen honeybee. J. Apic. Res. 21:3-6.

Kairo G., Poquet Y., Haji H., Tchamitchian S., Cousin M., Bonnet M., Pelissier M., Kretzschmar A., Belzunces L.P., Brunet J.-L. 2017. Assessment of the toxic effect of pesticides on honey bee drone fertility using laboratory and semifield approaches: a case study of fipronil. Environ. Toxicol. Chem. 36: 2345-2351.

Kefuss J.A., Nye W.P. 1970. The influence of photoperiod on the flight activity of honeybees. J. Apic. Res. 9:133-139.

Lensky Y., Demter M. 1985. Mating flights of the queen honey bee (Apis mellifera) in a subtropical climate. Comp. Biochem. Physiol. 81: 229-241.

Leoncini I., Le Conte Y., Costagliola G., Plettner E., Toth A.L., Wang M., Huang Z., Bécard J.M., Crauser D., Slessor K.N., Robinson G.E. 2004. Regulation of behavioral maturation by a primer pheromone produced by adult worker honey bees. Proc. Nat. Acad. Sci. USA 101: 17559-17564.

Loper G.M., Wolf W.W., Taylor O.R. 1987. Detection and monitoring of honeybee drone congregation areas by radar. Apidologie 18: 163-172.

Moritz R.F.A., Kryger P., Allsopp M. 1996. Competition for royalty in bees. Nature 384: 522 .

Morse RA, 1965. The effect of light on comb construction by honeybees. J. Apic. Res. 4: 23-29.
Neumann P., Moritz R.F.A. 2000. Testing genetic variance hypotheses for the evolution of polyandry in the honeybee (Apis mellifera L.). Insect. Soci. 47: 271-279.

Neves E.F., Faita M.R., Gaia Ld. O., Junior V.V.A., Antonialli-Junior W.F. 2011. Influence of climate factors on flight activity of drones of Apis mellifera (Hymenoptera: Apidae). Sociobiology 57: 107-113.

Ratnieks F.L.W., Keller L. 1998. Queen control of egg fertilization in the honey bee. Behav. Ecol. Sociobiol. 44: 57-61.

Taber III S., Wendel J. 1985. Concerning the number of times queen bees mate. J. Econ. Entomol. 51: 786-789.

Tanner G., Williams G.R., Mehmann M., Neumann P. 2012. Differential susceptibility of drone versus worker honey bees towards infections with Nosema ceranae and black queen cell virus? Proceedings of the $5^{\text {th }}$ European Conference of Apidology (EurBee 5), Halle-Saale, Germany, p. 239.

Wegener J., Lorenz M.W., Bienefeld K. 2010. Differences between queen- and worker-laid male eggs of the honey bee (Apis mellifera). Apidologie 41: 116-126.

Wharton K.E., Dyer F.C., Huang Z.Y., Getty T. 2007. The honeybee queen influences the regulation of colony drone production. Behav. Ecol. 18: 1092-1099.

Woyke J. 1963. What happens to diploid drone larvae in a honeybee colony. J. Apic. Res. 2: 73-75.

Woyke J. 1964. Genetic proof of the origin of drones from fertilized eggs of the honeybee. J. Apic. Res. 4: 7-11. 